\title{
Synthesis of New trans-Dehydrocrotonin Nitrogenated Derivatives and their Cytotoxic and DNA-Topoisomerase I Inhibitory Activities
}

\author{
Andressa Esteves-Souza, ${ }^{a}$ Kenia Pissinate, ${ }^{a}$ Maria A. M. Maciel ${ }^{b, c}$ and \\ Aurea Echevarria*,a \\ ${ }^{a}$ Departamento de Química, Universidade Federal Rural do Rio de Janeiro, \\ 23851-970 Seropédica-RJ, Brazil \\ ${ }^{b}$ Departamento de Química, Universidade Federal do Rio Grande do Norte, \\ 59072-970 Natal-RN, Brazil \\ cPrograma de Pós-graduação em Biotecnologia, Universidade Potiguar, \\ Laureate International Universities, Campus Salgado Filho, 59060-000 Natal-RN, Brazil
}

\begin{abstract}
A new series of 19-nor-clerodane diterpene derivatives was synthesized from the natural trans-dehydrocrotonin obtained from stem barks of Croton cajucara (Euphorbiaceae), a native medicinal plant of the Brazilian Amazon. The new derivatives were obtained by changes in the ketone moiety of trans-dehydrocrotonin leading to nitrogenated derivatives which are: three substituted hydrazine diterpenes, oxime, and methyloxime. The cytotoxic effect of the diterpene derivatives was evaluated by MTT (3-(4,5-dimethylthiazol-2-yl)-2,5-diphenyltetrazolium bromide) assay against Ehrlich carcinoma and K562 human leukemia cells. The cytotoxic activity of the hydrazine and oxime semi-synthetic derivatives was better than the one of the natural product trans-dehydrocrotonin. Moreover, all diterpenes were tested for their DNA topoisomerase I inhibitory activity, and the most effective one, in general, was observed to the phenyl-hydrazone derivative. Results indicated that the topoisomerase I inhibitory effect is correlated with the cytotoxic activity.
\end{abstract}

Keywords: Croton cajucara, diterpenes, trans-dehydrocrotonin, cytotoxic activity, DNA-topoisomerase I

\section{Introduction}

Medicinal plants are the dominant form of medicine in most countries, and the World Health Organization estimates that around $80 \%$ of the world population in developing countries relies on traditional plant medicines for primary healthcare needs. ${ }^{1}$

Many Euphorbiaceae plants are well known in different parts of the world as toxic and/or medicinal, and Croton is a large genus of this family widely distributed in tropical and subtropical regions of both hemispheres. Croton cajucara Benth, commonly known as "sacaca", is a medicinal plant largely grown in the Brazilian Amazon. Both stem bark and leaves are extensively used in the form of tea or pills for the treatment of several diseases. ${ }^{2,3}$ It is widely known in the Amazonian traditional phytotherapy for the treatment

*e-mail: echevarr@ufrrj.br

This paper was prepared in honor of the late Professor Angelo da Cunha Pinto of diarrhea and gastrointestinal disorders, ${ }^{3}$ liver diseases and weight loss, ${ }^{4}$ diabetes ${ }^{5}$ and high blood cholesterol levels. ${ }^{6}$ The terpenoid classes are the predominant special metabolite constituents of this genus, and the clerodane diterpenes, the prevalent type of Croton., ${ }^{3,7-10}$

Several clerodane diterpenes isolated from different species had been tested for their biological activities, and presented potentially useful medicinal properties, such as antimicrobial, ${ }^{11-14}$ anti-inflammatory, ${ }^{15,16}$ antiprotozoal, ${ }^{17-21}$ and antitumoral. ${ }^{22-26}$

The trans-dehydrocrotonin (1) is a nor-clerodane diterpene isolated from Croton cajucara as major component. ${ }^{27}$ Experimental laboratory animals and in vitro studies have shown that $\mathbf{1}$ has insecticidal, ${ }^{28}$ antigenotoxic, ${ }^{29}$ antiulcerogenic, ${ }^{3,30-33}$ anti-inflammatory, ${ }^{34}$ anti-leishmanial ${ }^{35}$ and antitumor effects. ${ }^{36-40}$

Our studies involving the Brazilian medicinal plants with potential cytotoxic activities led us to prepare a group of new clerodane diterpene derivatives starting from 
1 (Figure 1). Not only did we consider the fact that $\mathbf{1}$ is the principal and abundant component of $C$. cajucara ${ }^{27}$ but also the previous in vivo and in vitro results of antitumor activities. ${ }^{36,37}$ Clerodane 2, a natural component of $C$. cajucara stem bark, was also evaluated against representative neoplastic cell lines.
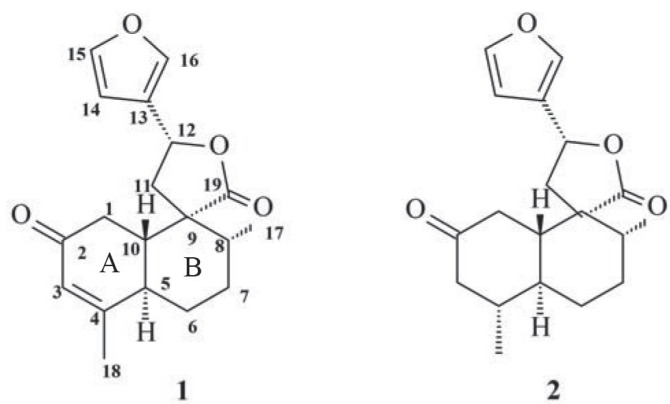

Figure 1. trans-Dehydrocrotonin (1) and trans-crotonin (2) clerodane diterpenes isolated from stem bark of Croton cajuacara.

In the present work, we report the synthesis of five new trans-dehydrocrotonin nitrogenated derivatives, and their in vitro evaluation of cytotoxic activity. The new derivatives were prepared from clerodane $\mathbf{1}$, previously isolated from the stem bark of Croton cajucara, ${ }^{3,27}$ and they were also evaluated against Ehrlich carcinoma and K562 human leukemia cells. Furthermore, the inhibitory action of the new derivatives, as well as the isolated natural compounds 1 and 2, was evaluated for DNA-topoisomerase I inhibition (Topo I).

\section{Results and Discussion}

\section{Synthesis and characterization}

Clerodane 1 was isolated from the stem bark of methanol extract of Croton cajucara, as previously described. ${ }^{3,27}$ The synthesis of the diterpene derivatives involved reactions of the $\mathrm{C}-2$ carbonyl group in the A ring. The structure of the clerodane skeleton was maintained to assure its natural feature in an attempt to preserve or enhance the cytotoxic activities previously observed. ${ }^{37,38}$ Thus, to construct a sensible series of trans-dehydrocrotonin derivatives for SAR purpose, some new semi-synthetic derivatives were prepared.

Those derivatives were performed including nitrogenated moieties at the ketone carbon (C-2) of A ring. The new compounds were the hydrazone derivatives, such as the unsubstituted hydrazone (3), methyl-hydrazone (4) and phenyl-hydrazone (5), as well as the oxime (6), and the methylated oxime (7). The synthetic route of the semisynthetic clerodanes 3-7 is outlined in Scheme 1.

Derivatives $3, \mathbf{4}$ and 5 were obtained from the treatment of $\mathbf{1}$ using hydrazine hydrate, methyl hydrazine and phenyl hydrazine, respectively, at room temperature, at different

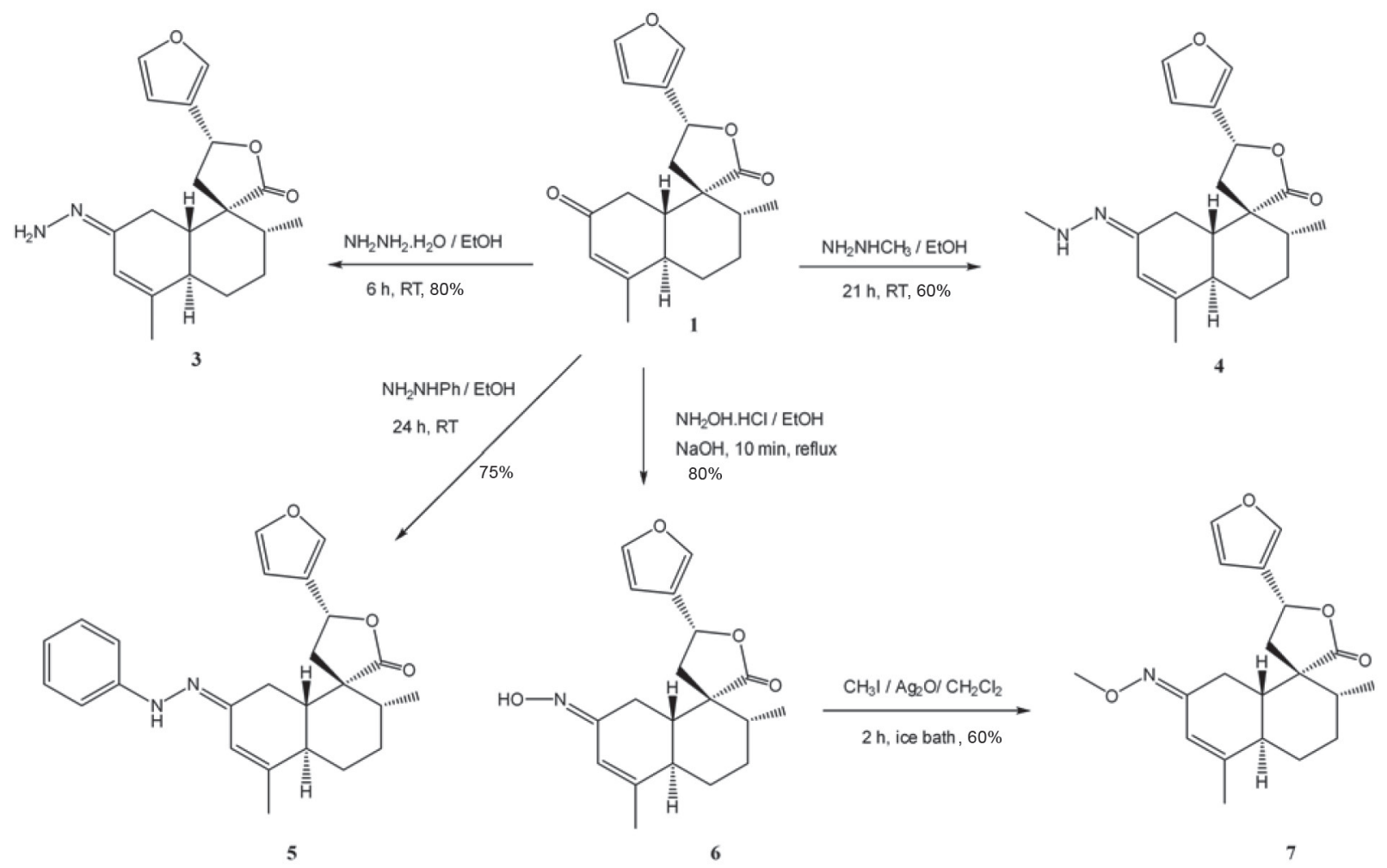

Scheme 1. Reagents and reaction conditions to prepare the semi-synthetic clerodanes 3-7. 
time reactions (6, 21 and $24 \mathrm{~h}$, respectively), in ethanol as solvent, following the previously reported procedure. ${ }^{41}$ The corresponding hydrazones were obtained in 80,60 and $75 \%$ yield for $\mathbf{3}, \mathbf{4}$ and $\mathbf{5}$, respectively. The oxime derivative (6) was prepared from 1 using hydroxylamine hydrochloride in basified ethanol with $\mathrm{NaOH}$, for 10 min under reflux, thus yielding $80 \%$. The reaction between $\mathbf{6}$ and methyl iodide, and $\mathrm{Ag}_{2} \mathrm{O}$, at low temperature, ${ }^{42}$ furnished the corresponding methylated oxime (7) in $60 \%$ yield. All the compounds were purified by silica gel chromatographic column using $\mathrm{CHCl}_{3}$, hexane and ethyl acetate as eluents. These new semi-synthetic diterpene derivatives 3-7 were characterized by infrared, ${ }^{1} \mathrm{H}$ and ${ }^{13} \mathrm{C}$ nuclear magnetic resonance (NMR) spectroscopy, and then briefly discussed.

The infrared spectra showed the absence of carbonyl moiety signal at $1666 \mathrm{~cm}^{-1}$ observed to trans-dehydrocrotonin ${ }^{27}$ and, the presence of absorption in the range of $1622-1599 \mathrm{~cm}^{-1}$ assigned to $\mathrm{C}=\mathrm{N}$ group of hydrazone derivatives, 3,4 and $5 .{ }^{1} \mathrm{H}$ NMR spectra of $\mathbf{3}, 4$ and $\mathbf{5}$ presented a similar pattern, detaching the chemical shifts in the range of $\delta 6.51-6.98$, and signals corresponding to aromatic hydrogens of phenyl-hydrazone derivative (5) were observed. The $\mathrm{N}-\mathrm{H}$ signal was observed in the range of $\delta$ 5.00-6.00. The ${ }^{13} \mathrm{C}$ NMR spectra of $\mathbf{3}, \mathbf{4}$ and $\mathbf{5}$ presented coherent changes to respect $\mathbf{1}$ in accordance to the moiety nature attached to $\mathrm{C}-2$. Typical values of imino function were observed for $\mathrm{C}-2$ in the range of $\delta 151.9-152.0$, and smaller variations in the carbons $\mathrm{C}-1, \mathrm{C}-3$ and $\mathrm{C}-4$, as expected.

The infrared spectra of $\mathbf{6}$ and $\mathbf{7}$ derivatives showed absorptions of 1635 and $1610 \mathrm{~cm}^{-1}$, respectively, assigned to $\mathrm{C}=\mathrm{N}$ moiety, instead of $\mathrm{C}=\mathrm{O}$ absorption of trans-dehydrocrotonin $\left(1666 \mathrm{~cm}^{-1}\right) .{ }^{27}$ The ${ }^{1} \mathrm{H}$ NMR chemical shifts observed for $\mathbf{6}$, the oxime derivative, and for methyl-oxime (7) were coherent with the structure proposal, in which $\mathrm{H}-3$ appeared in $\delta 6.13$ for 7, presenting deshielding effect when compared to $6(\delta 5.89)$, due to the stereo-spatial position of the methyl group. The signal corresponding to the hydroxyl-oxime of $\mathbf{6}$ appeared in $\delta 8.05$ as a wide singlet. ${ }^{13} \mathrm{C}$ NMR chemical shifts were in accordance to the proposal structures; $\delta 156.2$ and 158.7 were attributed to C-2 at $\mathbf{6}$ and 7, respectively; and, shielding effect ( $\gamma$ effect) was observed at C-3, with $\Delta \delta 6.5$ and $\Delta \delta 10.0$ when compared to $\mathbf{1}$, for $\mathbf{6}$ and $\mathbf{7}$, respectively.

\section{Cytotoxic effects}

The cytotoxic action of special metabolites isolated from $C$. cajucara Benth stem bark extracts against tumor cells ${ }^{36,37}$ led us to continue studying the possible action of the new semi-synthetic derivatives of trans-dehydrocrotonin diterpene (1). The antiproliferative effect of 1-7 against the ascitic Ehrlich carcinoma and human leukemia K562 cells was evaluated. Assays were performed using the MTT method ${ }^{43}$ with quercetin and vincristine as positive controls for Ehrlich and K562 leukemia, respectively.

In vitro assays using Ehrlich carcinoma cells with 4, 5, 6 and $\mathbf{7}$ nitrogenated derivatives showed a more significant antiproliferative activity when compared to $\mathbf{1}$, the major active component of $C$. cajucara, previously evaluated by Grynberg et al. ${ }^{36}$ with dose dependent responses over $48 \mathrm{~h}$ culture period. $\mathrm{IC}_{50}$ values $45.78 \pm 4.35,16.78 \pm 1.42$, $21.88 \pm 1.96$ and $43.43 \pm 3.96 \mu \mathrm{mol} \mathrm{L}^{-1}$ were also compared to quercetin $\left(\mathrm{IC}_{50}=44 \mu \mathrm{mol} \mathrm{L} \mathrm{L}^{-1}\right)$, as shown in Table 1 . Interestingly, the unsubstituted hydrazone derivative $\mathbf{3}$ did not present any significant activity until the maximum concentration of $50 \mu \mathrm{mol} \mathrm{L}^{-1}$ used in the assays, thus suggesting a positive contribution of hydrophobic effect.

Table 1. $\mathrm{IC}_{50}$ values for nor-clerodane diterpene derivatives against Ehrlich carcinoma and K562 leukemia cells

\begin{tabular}{lcc}
\hline \multirow{2}{*}{ Derivative } & \multicolumn{2}{c}{$\left.\mathrm{IC}_{50} \pm \mathrm{SD} /(\mu \mathrm{mol} \mathrm{L})^{-1}\right)$} \\
\cline { 2 - 3 } $\mathbf{1}$ & \multicolumn{1}{c}{ Ehrlich } & $\mathrm{K} 562$ \\
$\mathbf{2}$ & $>50^{\mathrm{a}}$ & $>50$ \\
$\mathbf{3}$ & $>50$ & $>50$ \\
$\mathbf{4}$ & $45.78 \pm 4.35$ & $7.85 \pm 1.49$ \\
$\mathbf{5}$ & $16.78 \pm 1.42$ & $13.08 \pm 1.12$ \\
$\mathbf{6}$ & $21.88 \pm 1.96$ & $>50$ \\
$\mathbf{7}$ & $43.43 \pm 3.96$ & $40.72 \pm 5.63$ \\
Quercetin & $44.0 \pm 3.9$ & - \\
Vincristine & - & $0.060 \pm 0.001$ \\
\hline
\end{tabular}

${ }^{\mathrm{a}} \mathbf{1}, \mathrm{IC}_{50}=166 \mu \mathrm{mol} \mathrm{L}{ }^{-1}, 37 \mathrm{~b} \mathbf{2}, \mathrm{IC}_{50}=164 \mu \mathrm{mol} \mathrm{L}{ }^{-1} \cdot{ }^{37} \mathrm{SD}:$ standard deviation.

The inhibitory effect on K562 cells in vitro, after $96 \mathrm{~h}$ in culture, was not observed for $\mathbf{1}$ nor $\mathbf{2}$ until the dose of $50 \mu \mathrm{mol} \mathrm{L}{ }^{-1} \cdot{ }^{37}$ However, the new nitrogenated derivatives and the unsaturated alcohol presented cytotoxic effect against K562, also with dose dependent responses, with $\mathrm{IC}_{50}=24.74 \pm 2.3(\mathbf{3}), 7.85 \pm 1.49$ (4), $13.08 \pm 1.12(\mathbf{5})$, and $40.72 \pm 5.63 \mu \mathrm{mol} \mathrm{L}^{-1}(7)$, as shown in Table 1 .

\section{DNA-topoisomerase I inhibitory effect}

The conversion of supercoiled plasmid DNA to relaxed DNA by human topoisomerase I (Topo 1) was examined in the presence of $\mathbf{1}, \mathbf{2}$ and the new semi-synthetic diterpene derivatives. The activity of the compounds on Topo I was observed through relaxation assays using pBR322 plasmid DNA. Campothecin, a well-known Topo 1 enzyme inhibitor, was used as a positive control..$^{44,45}$ 
Results were observed through the alteration of the electrophoretic mobility of pBR322 plasmid DNA, combining Topo I action and the drugs at $200 \mu \mathrm{mol} \mathrm{L}-1$. After this development, the results were analyzed with ethidium bromide in UV light, and recorded by photographing with a digital camera. As shown in Figure 2, the mobility of supercoiled closed circular double-stranded plasmid DNA increased on Topo I mediated relaxation, when subjected to electrophoresis with ethidium bromide (line 3). In the presence of $200 \mu \mathrm{mol} \mathrm{L} \mathrm{L}^{-1}$ campothecin (positive control), the relaxation effect was not observed (line 1). The relaxation inhibitory effect was also observed in the presence of Topo I with $\mathbf{1 , 3 , 4 , 5 , 6}$, and $\mathbf{7}$. When the assays were performed at $20 \mu \mathrm{mol} \mathrm{L}{ }^{-1}$, only $\mathbf{4}$ did not show inhibitory effect on Topo I. These results must justify the cytotoxic activities observed.

$$
\text { Line: } \begin{array}{lllllllll}
9 & 8 & 7 & 6 & 5 & 4 & 3 & 2 & 1
\end{array}
$$

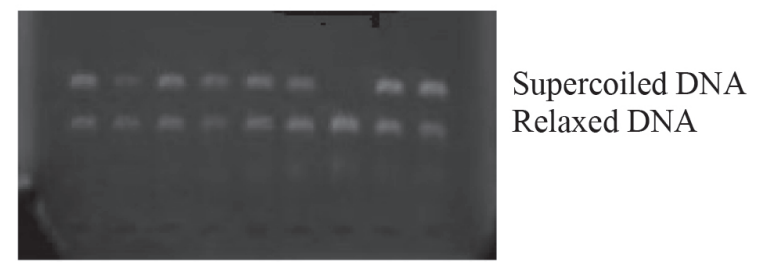

Figure 2. Effect of trans-dehydrocrotonin derivatives in $200 \mu \mathrm{mol} \mathrm{L} \mathrm{L}^{-1}$ on Topo I. Line 1: $0.25 \mu \mathrm{g}$ DNA pBR322 + 1U Topo I + campothecin $200 \mu \mathrm{mol} \mathrm{L}{ }^{-1}$; line 2: $0.25 \mu \mathrm{g}$ DNA pBR322; line 3: $0.25 \mu \mathrm{g}$ DNA pBR322 $+1 \mathrm{U}$ Topo I; line 4: $0.25 \mu \mathrm{g}$ DNA pBR322 + 1U Topo I + 1; line 5: $0.25 \mu \mathrm{g}$ DNA pBR322 + 1U Topo I + 6; line 6: $0.25 \mu \mathrm{g}$ DNA pBR322 + 1U Topo I + 7; line 7: $0.25 \mu \mathrm{g}$ DNA pBR322 + 1 U Topo I + $\mathbf{3}$; line 8: $0.25 \mu \mathrm{g}$ DNA pBR322 + 1U Topo I + 4; line 9: $0.25 \mu \mathrm{g}$ DNA pBR322 + 1U Topo I + 5 .

\section{Conclusions}

In summary, new clerodane diterpene derivatives were synthesized from trans-dehydrocrotonin, the major bioactive metabolite of the Amazonian medicinal plant Croton cajucara, by simple processes and with good yields. In vitro studies of cytotoxic activities against Ehrlich carcinoma and K562 leukemia cells showed that the nitrogenated derivatives were more active than the natural products $\mathbf{1}$ and $\mathbf{2}$, especially phenyl and methyl-hydrazone. The study of a possible mechanism of action showed the strong inhibitory effect of the nitrogenated derivatives, except 4, on DNA-topoisomerase I, in the relaxation assay.

\section{Experimental}

\section{Chemistry}

Reagents and apparatus

The melting points were determined on a Quimis hot stage instrument. Infrared spectra $\left(\mathrm{KBr}\right.$ pellets or $\left.\mathrm{CHCl}_{3}\right)$ were recorded on a PerkinElmer 1605 spectrometer and expressed in $\mathrm{cm}^{-1}$. The microanalyses were carried out with a Carlo Erba EA-1110 CHNS-O Elemental Analyser. ${ }^{1} \mathrm{H}$ and ${ }^{13} \mathrm{C}$ NMR spectra were obtained on a Bruker AC 200 spectrometer (200 and $50.3 \mathrm{MHz}$ ), using $\mathrm{CDCl}_{3}$ or DMSO- $d_{6}$ as solvent, and TMS as internal standard. Elemental analyses were performed on a PerkinElmer 2400 CHN in the Laboratory of Environmental Science at the State University of Northern Rio de Janeiro (UENF). Thin layer chromatography (TLC) analyses were performed on silica gel 60 F254 plates. All the reagents were purchased from Merck or Sigma-Aldrich.

\section{Vegetal material and the isolation of $\mathbf{1}$ and $\mathbf{2}$}

Plant material, Croton cajucara Benth was collected in Jacundá-PA (Amazon region, Brazil), and botanically authenticated by Dr Nelson A. Rosa, Museu Paraense Emílio Goeldi. A voucher specimen No. 247 is deposited at the Herbarium of the same museum. The methanolic extraction from the powdered bark of Croton cajucara and the isolation of $\mathbf{1}$ and $\mathbf{2}$ was carried out as previously reported. ${ }^{3,27}$

General method for the preparation of hydrazone derivatives (3-5)

For the solution of $\mathbf{1}(0.30 \mathrm{mmol})$ in ethanol $(1 \mathrm{~mL})$, $1.2 \mathrm{mmol}$ of corresponding hydrazine was added; the reaction mixture was stirred for $6 \mathrm{~h}$ at room temperature for hydrazine hydrate, and for 21 and $24 \mathrm{~h}$ under reflux for methyl and phenyl-hydrazine, respectively. At these times, the hydrazine excess had been evaporated, and the crude products were purified by flash chromatography on silica gel (EtOAc:hexane, 10:90) for $\mathbf{4}$ and $\mathbf{5}$, and by recrystallization from EtOH and powdered charcoal for $\mathbf{3}$.

\section{2-Hydrazone-dehydrocrotonin (3)}

$80 \%$ yield; mp $119-121{ }^{\circ} \mathrm{C}$; IR (KBr) $v_{\max } / \mathrm{cm}^{-1} 3433$, 2927-2876, 1695, 1378; ${ }^{1} \mathrm{H} \mathrm{NMR}\left(200 \mathrm{MHz}, \mathrm{CDCl}_{3}\right) \delta 1.11$ (3H), $1.66(1 \mathrm{H}, \beta), 1.84(1 \mathrm{H}, \alpha), 1.94(3 \mathrm{H}$, br s), $2.15(1 \mathrm{H}$, $\alpha), 2.22(1 \mathrm{H}), 2.35-2.39(1 \mathrm{H}), 2.48(1 \mathrm{H}, \beta), 3.14(1 \mathrm{H}, \mathrm{br} \mathrm{s})$, $3.44(2 \mathrm{H}), 5.40(1 \mathrm{H}), 5.86(1 \mathrm{H}), 2.35-2.39(1 \mathrm{H}), 6.38(1 \mathrm{H}$, s), $7.42(2 \mathrm{H}) ;{ }^{13} \mathrm{C} \mathrm{NMR}\left(50 \mathrm{MHz}, \mathrm{CDCl}_{3}\right) \delta 17.4,21.6,27.5$, 28.5, 30.1, 38.8, 40.9, 41.6, 51.8, 45.5, 72.0, 108.8, 124.1, 125.2, 140.2, 143.8, 151.9, 160.1, 177.4. Anal. calcd. for $\mathrm{C}_{19} \mathrm{H}_{24} \mathrm{~N}_{2} \mathrm{O}_{3}$ : C, 69.49; H, 7.37; N, 8.53. Found: C, 69.73; $\mathrm{H}, 7.28 ; \mathrm{N}, 8.72$.

\section{2-Methylhydrazone-dehydrocrotonin (4) $60 \%$ yield; mp $135-136^{\circ} \mathrm{C}$; IR (KBr) $v_{\max } / \mathrm{cm}^{-1} 3296$,}


2960-2864, 1746, 1318; ${ }^{1} \mathrm{H}$ NMR (200 MHz, DMSO- $\left.d_{6}\right)$ $\delta 1.10(3 \mathrm{H}), 1.59(1 \mathrm{H}, \beta), 1.71(2 \mathrm{H}), 1.81(1 \mathrm{H}, \alpha), 2.11$ $(1 \mathrm{H}, \alpha), 2.20(1 \mathrm{H}), 2.47(1 \mathrm{H}, \mathrm{m}), 2.57(1 \mathrm{H}, \beta), 2.77(3 \mathrm{H})$, $2.86(1 \mathrm{H}$, br s), $5.58(2 \mathrm{H}$, br s), $5.86(1 \mathrm{H}), 6.75(1 \mathrm{H}, \mathrm{s})$, $7.79(1 \mathrm{H}), 7.93(1 \mathrm{H}) ;{ }^{13} \mathrm{C} \mathrm{NMR}\left(50 \mathrm{MHz}, \mathrm{CDCl}_{3}\right) \delta 17.6$, 20.8, 25.5, 28.3, 30.2, 38.0, 40.9, 41.0, 44.1, 51.6, 71.7, $108.9,124.1,125.4,140.6,144.4,177.4$. Anal. calcd. for $\mathrm{C}_{20} \mathrm{H}_{26} \mathrm{~N}_{2} \mathrm{O}_{3}$ : C, 70.15; H, 7.65; N, 8.18. Found: C, 70.37; $\mathrm{H}, 7.43 ; \mathrm{N}, 8.24$.

\section{2-Phenylhydrazone-dehydrocrotonin (5)}

$75 \%$ yield; mp 171-172 ${ }^{\circ} \mathrm{C}$; IR (KBr) $v_{\max } / \mathrm{cm}^{-1} 3328$, 2958-2858, 1743, 1322; ${ }^{1} \mathrm{H}$ NMR $\left(200 \mathrm{MHz}, \mathrm{CDCl}_{3}\right) \delta 1.13$ $(3 \mathrm{H}, \mathrm{d}, J 5.1 \mathrm{~Hz}), 1.62(1 \mathrm{H}, \beta), 1.70(2 \mathrm{H}), 1.77(2 \mathrm{H}), 1.84$ (3H, br s), $1.94(1 \mathrm{H}, \alpha), 2.18(1 \mathrm{H}, \alpha, \mathrm{d}, J 3.3 \mathrm{~Hz}), 2.24-2.27$ (1H), 2.57 (1H, br s, $\beta), 2.33-2.70(1 \mathrm{H}, \mathrm{dd}, J 14.0,6.3 \mathrm{~Hz})$, $2.83(1 \mathrm{H}$, br s), $5.51(1 \mathrm{H}), 5.59(1 \mathrm{H}, \mathrm{sl}), 6.48(1 \mathrm{H}), 6.83$ $(2 \mathrm{H}, \mathrm{dd}, J 0.7,8 \mathrm{~Hz}), 6.96(1 \mathrm{H}, \mathrm{d}, J 6.3 \mathrm{~Hz}), 6.98(2 \mathrm{H}, \mathrm{d}$, $J 0.7 \mathrm{~Hz}), 7.58(1 \mathrm{H}), 7.59(1 \mathrm{H}) ;{ }^{13} \mathrm{C} \mathrm{NMR}\left(50 \mathrm{MHz}, \mathrm{CDCl}_{3}\right)$ $\delta 17.4,21.4,26.0,27.6,30.0,39.6,40.4,41.7,45.9,51.5$, 72.3, 108.0, 113.2, 120.3, 122.3, 126.6, 129.1, 139.1, 144.3, 152.0, 153.1, 166.1, 177.4. Anal. calcd. for $\mathrm{C}_{25} \mathrm{H}_{28} \mathrm{~N}_{2} \mathrm{O}_{3}$ : C, 74.23; H, 6.98; N, 6.93. Found: C, 74.37; H, 6.72; N, 7.04.

The preparation of 2-oxime-dehydrocrotonin (6)

For the solution of $\mathbf{1}(0.5 \mathrm{mmol}), \mathrm{HONH}_{2}-\mathrm{HCl}$ (0.8 mmol), $2 \mathrm{~mL}$ of ethanol in $0.4 \mathrm{~mL}$ of water was added under stirring $\mathrm{NaOH}$ (2.75 mmol). The mixture had been refluxed for $10 \mathrm{~min}$, and when it reached the room temperature, it was added to an acid solution $(0.3 \mathrm{~mL} \mathrm{HCl}$ and $2 \mathrm{~mL}$ water). After that, the precipitate was filtered, washed with water and dried at room temperature. $80 \%$ yield; mp 197-198 ${ }^{\circ} \mathrm{C}$; IR (KBr) $v_{\max } / \mathrm{cm}^{-1} 3279$, 29412860, 1751, 1635, 1463-1436, 1351, 1184; ${ }^{1} \mathrm{H}$ NMR $\left(200 \mathrm{MHz}, \mathrm{CDCl}_{3}\right) \delta 1.87(1 \mathrm{H}, \alpha), 1.12(3 \mathrm{H}, \mathrm{d}, J 5.1 \mathrm{~Hz})$, $1.55(1 \mathrm{H}), 1.63(1 \mathrm{H}, \beta), 1.74(1 \mathrm{H}), 1.82(3 \mathrm{H}$, br s), 2.15 $(1 \mathrm{H}, \alpha), 2.25(2 \mathrm{H}), 2.44(2 \mathrm{H}, \mathrm{t}, J 8.3 \mathrm{~Hz}), 2.92(1 \mathrm{H}, \beta), 3.44$ $(1 \mathrm{H}, \mathrm{d}, J 5.1 \mathrm{~Hz}), 5.40(1 \mathrm{H}, \mathrm{t}, J 8.3 \mathrm{~Hz}), 5.89(1 \mathrm{H}), 6.50$ $(1 \mathrm{H}, \mathrm{s}), 7.43(1 \mathrm{H}), 7.49(1 \mathrm{H}), 8.05\left(1 \mathrm{H}\right.$, br s); ${ }^{13} \mathrm{C} \mathrm{NMR}$ $\left(50 \mathrm{MHz}, \mathrm{CDCl}_{3}\right) \delta 17.6,21.3,28.5,30.2,38.4,41.8,46.3$, 51.8, 72.1, 108.2, 119.2, 125.1, 140.0, 144.2, 153.2, 156.2, 177.4. Anal. calcd. for $\mathrm{C}_{19} \mathrm{H}_{23} \mathrm{NO}_{4}$ : C, 69.28; H, 7.04; N, 4.25. Found: C, 69.41; H, 6.98; N, 4.32.

The preparation of 2-O-methyloxime-dehydrocrotonin (7)

For the solution of $3(0.15 \mathrm{mmol})$ in $\mathrm{CH}_{2} \mathrm{Cl}_{2}(2 \mathrm{~mL})$, $\mathrm{Ag}_{2} \mathrm{O}(0.22 \mathrm{mmol})$ and $\mathrm{CH}_{3} \mathrm{I}(0.75 \mathrm{mmol})$ were slowly added. The solution was stirred at room temperature for $3 \mathrm{~h}$. After that, $\mathrm{CH}_{2} \mathrm{Cl}_{2}$ was evaporated, and the residue was purified by flash chromatography on silica gel (hexane:AcOEt, 90:10), thus providing product 7 as an oil in $60 \%$ yield. IR $\left(\mathrm{CHCl}_{3}\right) v_{\max } / \mathrm{cm}^{1} 2929-2860,1749$, 1610, 1319; ${ }^{1} \mathrm{H}$ NMR $\left(200 \mathrm{MHz}, \mathrm{CDCl}_{3}\right) \delta 1.23(3 \mathrm{H}$, br s), $1.66(1 \mathrm{H}, \beta), 1.91(1 \mathrm{H}, \alpha), 2.00(2 \mathrm{H}), 2.17(1 \mathrm{H}, \mathrm{m}, \alpha)$, 2.44 (1H, t, J 7.6 Hz), 2.93 (1H, m, $\beta), 3.17$ (1H, br s), 5.05 (3H, br s), 5.42 (1H, br s), 6.13 (1H, br s), $6.53(1 \mathrm{H}), 7.44$ $(1 \mathrm{H}), 7.49(1 \mathrm{H}) ;{ }^{13} \mathrm{C} \mathrm{NMR}\left(50 \mathrm{MHz}, \mathrm{CDCl}_{3}\right) \delta$ 17.6, 22.0, 28.0, 30.0, 39.4, 39.7, 40.3, 44.0, 45.1, 51.6, 64.7, 72.3, 108.1, 116.6, 126.7, 140.0, 144.5, 158.6, 166.3, 177.2. Anal. calcd. for $\mathrm{C}_{20} \mathrm{H}_{25} \mathrm{NO}_{4}$ : C, 69.95; H, 7.34; N, 4.08. Found: C, 70.09; H, 7.21; N, 4 .

\section{Biological assays}

\section{Materials}

The dye MTT (3-(4,5-dimethylthiazol-2-yl)2,5-diphenyltetrazolium bromide) was obtained from Sigma Co. (USA); quercetine and vincristine sulfate, used as positive control in cytotoxic assays, were obtained from Sigma-Aldrich Co. (USA) and Merck Co. (Germany), respectively.

\section{Cell culture}

Ehrlich carcinoma cells were maintained for 12-14 days in Swiss mice. The tumor cell cultures were initiated from mouse Ehrlich ascites with at least one in vitro passage prior to use. K562 cells were maintained in RPMI 1640 medium, containing 10\% fetal calf serum (FCS), $100 \mathrm{U} \mathrm{mL}^{-1}$ penicillin $\mathrm{G}$ and $100 \mu \mathrm{g} \mathrm{mL}^{-1}$ streptomycin. The cell cultures were incubated at $37{ }^{\circ} \mathrm{C}$ in a $5 \% \mathrm{CO}_{2}$ humidified atmosphere.

\section{Drugs and cytotoxic assay}

The stock solutions of the diterpene derivatives were prepared in DMSO. The drug cytotoxicity assays were performed as previously described by Mosmann, ${ }^{43}$ using MTT for viable cell measurements. The aliquots of $5 \times 10^{5}$ cells mL $\mathrm{mL}^{-1}$ (Ehrlich) and $2 \times 10^{4}$ cells $\mathrm{mL}^{-1}(\mathrm{~K} 562)$ were seeded in triplicate onto 96-microtiter flat well plates in RPMI 1640 medium supplemented with $10 \%$ fetal calf serum, $50 \mu \mathrm{M}$ 2-mercaptoethanol, $100 \mathrm{IU} \mathrm{mL}^{-1}$ penicillin and $100 \mu \mathrm{g} \mathrm{mL} \mathrm{m}^{-1}$ streptomycin. The drugs dissolved in DMSO at various concentrations were added to the culture and adjusted to a final DMSO concentration of $0.2 \%(\mathrm{v} / \mathrm{v})$. The cultures were maintained under $5 \% \mathrm{CO}_{2}$ at $37{ }^{\circ} \mathrm{C}$. Cellular viability was determined in the presence or absence of diterpenes, using the standard MTT assay. ${ }^{43}$ Quercetine and vincristine were used as positive control to Ehrlich and K562, respectively. All determinations were carried 
out in triplicate. After $48 \mathrm{~h}$ (Ehrlich) and $96 \mathrm{~h}$ (K562), at $37{ }^{\circ} \mathrm{C}$ under $5 \% \mathrm{CO}_{2}$, the cultures were incubated with MTT ( $5 \mathrm{mg} \mathrm{mL}^{-1}$ ) for $3 \mathrm{~h}$. The formazan produced by live cells were solubilized with acidic isopropanol, and the absorbance was measured at $570 \mathrm{~nm}$. $\mathrm{IC}_{50}$ values were obtained by linear regression analysis of the absorbance (percent) versus the log of drug concentration. The data are expressed as means \pm standard deviation $(\mathrm{SD})$ of 3 independent experiments. Statistical significance was assessed by the Student's $t$-test, $p<0.05$ was considered significant difference.

\section{DNA-topoisomerase I assay}

Topo I inhibition was determined by relaxation assay, which was carried out as described in the TopoGEN screening kit. For Topo I, one unit of the enzyme was utilized to relax $0.125 \mu \mathrm{g}$ of the supercoiled $\varphi \times 174$ plasmid DNA. The reaction mixture $(10 \mu \mathrm{L})$ contained the drug, DNA, assay buffer, $1 \mathrm{U}$ of Topo I and water. The mixture was incubated at $37^{\circ} \mathrm{C}$ for $30 \mathrm{~min}$, and the reaction was finalized by the addition of $1 \mu \mathrm{L}$ of dye solution containing $25 \%$ bromophenol blue, $50 \%$ glycerol and $10 \%$ SDS. Reaction products were loaded onto a $1 \%$ agarose gel, containing ethidium bromide. Electrophoresis was carried out in trisacetate-EDTA, pH 8.5, at $15 \mathrm{~V}$, for $3.5 \mathrm{~h}$; and then, it was photographed with a digital camera by illumination.

\section{Supplementary Information}

Supplementary data $\left({ }^{1} \mathrm{H}\right.$ and ${ }^{13} \mathrm{C}$ NMR spectra) are available free of charge at http://jbcs.sbq.org.br as PDF file.

\section{Acknowledgments}

The authors thank the Coordenação de Aperfeiçoamento de Pessoal de Nível Superior (CAPES), Conselho Nacional de Desenvolvimento Científico e Tecnológico (CNPq) and Fundação de Amaparo à Pesquisa do Estado do Rio de Janeiro (FAPERJ) for financial support and the fellowships.

\section{References}

1. Sampson, J. H.; Phillipson, J. D.; Bowery, N. G.; O’Neill, M. J.; Houston, J. G.; Lewis, J. A.; Phytother. Res. 2000, 14, 24.

2. Salatino, A.; Salatino, M. L. F.; Negri, G.; J. Braz. Chem. Soc. 2007, 18, 11.

3. Maciel, M. A. M.; Pinto, A. C.; Arruda, A. C.; Pamplona, S. G. S. R.; Vanderlinde, F. A.; Lapa, A. J.; Cólus, I. M. S.; Echevarria, A.; Grynberg, N. F.; Farias, R. A. F.; Luna, A. M. C.; Rao, V. S. N.; J. Ethnopharmacol. 2000, 70, 41.
4. Grassi-Kassisse, D. M.; Wolf-Nunes, V.; Miotto, A. M.; Farias-Silva, E.; Souza-Brito, A. R. M.; Nunes, D. S.; SpadariBratfisch, R. C.; J. Pharm. Pharmacol. 2003, 55, 253.

5. Rodrigues, G.; Marcolin, E.; Bona, S.; Porawski, M.; Lehmann, M.; Marroni, N. P.; Arq. Gastroenterol. 2010, 47, 301.

6. Silva, R. M.; Santos, F. A.; Maciel, M. A. M.; Pinto, A. C.; Rao, V. S. N.; Planta Med. 2001, 67, 763.

7. Huang, W.; Li, G.; Wu, Y.; Ge, W.; Chung, H. Y.; Ye, W.; Li, Y.; Wang, G.; Heterocycles 2014, 89, 1585.

8. Yang, L.; Zhang, Y.; Wu, Z.; Chen, N.; Jiang, S.; Li, Y.; Wang, G.; Chem. Lett. 2016, 45, 1235.

9. Li, R.; Morris-Natschke, S. L.; Lee, K.; Nat. Prod. Rep. 2016 , $33,1166$.

10. Liu, C. P.; Xu, J. B.; Zhao, J. X.; Xu, C. H.; Dong, L.; Ding, J.; Yue, J. M.; J. Nat. Prod. 2014, 77, 1013.

11. Gupta, V. K.; Tiwari, N.; Gupta, P.; Verma, S.; Pal, A.; Srivastava, S. K.; Darokar, M. P.; Phytomedicine 2016, 23, 654.

12. Cavin, A. L.; Hay, A. E.; Marston, A.; Stoeckli-Evans, H.; Diallo, D.; Hostettmann, K.; J. Nat. Prod. 2006, 69, 768.

13. Huang, Z.; Jiang, M. Y.; Zhou, Z. Y.; Xu, D.; Z. Naturforsch. B: J. Chem. Sci. 2010, 65, 83.

14. Bayor, M. T.; Ayim, J. S. K.; Marston, G.; Phillips, R. M.; Shnyder, S. D.; Wheelhouse, R. T.; Wright, C. W.; Nat. Prod. Commun. 2008, 3, 1875.

15. Wu, T.; Cheng, Y.; Chen, C.; Ng, L.; Chou, L.; Huang, L.; Chen, Y.; Kuo, S.; El-Shazly, M.; Wu, Y.; Chang, F.; Liaw, C.; Molecules 2014, 19, 2049.

16. Dai, S. J.; Liang, D. D.; Ren, Y.; Liu, K.; Shen, L.; Chem. Pharm. Bull. 2008, 56, 207.

17. Mambu, L.; Grellier, P.; Florent, L.; Joyeau, R.; Ramanitrahasimbola, D.; Rasoanaivo, P.; Frappier, F.; Phytochemsitry 2006, 67, 444.

18. Harinantenaina, L.; Takahara, Y.; Nishizawa, T.; Kohchi, C.; Soma, G. I.; Asakawa, Y.; Chem. Pharm. Bull. 2006, 54, 1046.

19. Munro, T. A.; Duncan, K. K.; Xu, W.; Wang, Y.; Liu-Chen, L. Y.; Carlezon Jr, W. A.; Cohen, B. M.; Beguin, C. B.; Bioorg. Med. Chem. 2008, 16, 1279.

20. Chang, H. L.; Chang, F. R.; Chen, J. S.; Wang, Y. P.; Wu, Y. H.; Wang, C. C.; Wu, Y. C.; Hwang, T. L.; Eur. J. Pharmacol. 2008, 586, 332.

21. Bautista, E.; Toscano, A.; Calzada, F.; Díaz, E.; Yepez-Mulia, L.; Ortega, A.; J. Nat. Prod. 2013, 76, 1970.

22. Qiu, M.; Cao, D.; Gao, Y.; Li, S.; Zhu, J.; Yang, B.; Zhou, L.; Zhou, Y.; Jin, J.; Zhao, Z.; Fitoterapia 2016, 108, 81.

23. Maciel, M. A. M.; Pinto, A. C.; Brabo, S. N.; Silva, M. N.; Phytochemistry 1998, 49, 823.

24. Vieira-Júnior, G. M.; Dutra, L. A.; Ferreira, P. M.; Moraes, M. O.; Costa-Lotufo, L. V.; O’Pessoa, C.; Torres, R. B.; Boralle, N.; Bolzani, V. S.; Cavalheiro, A. J.; J. Nat. Prod. 2011, 74, 776. 
25. Jullian, V.; Bounduelle, C.; Valentin, L.; Acebey, L.; Duigou, A. G.; Prevostb, M. F.; Sauvain, M.; Bioorg. Med. Chem. 2005, 15, 5065.

26. Williams, R. B.; Norris, A.; Miller, J. S.; Birkinshaw, C.; Ratovoson, F.; Andriantsiferana, R.; Rasamison, V. E.; Kingston, D. G. I.; J. Nat. Prod. 2007, 70, 206.

27. Kubo, I.; Asaka, Y.; Shibata, K.; Phytochemistry 1991, $30,2546$.

28. Poersch, A.; Santos, F. V.; Maciel, M. A. M.; Câmara, J. K. P.; Dantas, T. N. C.; Cólus, I. M. S.; Mutat. Res. 2007, 629, 14.

29. Souza-Brito, A. R. M.; Rodriguez, J. A.; Hiruma-Lima, C. A.; Haun, M.; Nunes, D. S.; Planta Med. 1998, 64, 126.

30. Hiruma-Lima, C. A.; Spadari-Bratfisch, R. C.; Grassi-Kassisse, D. M.; Souza-Brito, A. R. M.; Planta Med. 1999, 65, 325.

31. Rodriguez, J. A.; Hiruma-Lima, C. A.; Souza-Brito, A. R. M.; Hum. Exp. Toxicol. 2004, 23, 455.

32. Hiruma-Lima, C. A.; Tona, W.; Gracioso, J. S.; Almeida, A. B. A.; Batista, L. M.; Magri, L.; Paula, A. C. B.; Soares, F. R.; Nunes, D. S.; Souza-Brito, A. R. M.; Biol. Pharm. Bull. 2002, 25,425 .

33. Carvalho, J. C. T.; Silva, M. F. C.; Maciel, M. A. M.; Pinto, A. C.; Nunes, D. S.; Lima, R. M.; Bastos, J. K.; Sarti, S. J.; Planta Med. 1996, 62, 402 .

34. Silva, R. M.; Oliveira, F. M.; Cunha, K. M. A.; Maia, J. L.; Maciel, M. A. M.; Pinto, A. C.; Nascimento, N. R. F.; Santos, F. A.; Rao, V. S. N.; Vasc. Pharmacol. 2005, 43, 11.
35. Lima, G. S.; Castro-Pinto, D. B.; Machado, G. C.; Maciel, M. A. M.; Echevarria, A.; Phytomedicine 2015, 22, 1133.

36. Grynberg, N. F.; Echevarria, A.; Lima, J. E.; Pamplona, S. S. R.; Pinto, A. C.; Maciel, M. A.; Planta Med. 1999, 65, 687.

37. Maciel, M. A. M.; Martins, J. R.; Pinto, A. C.; Kaiser, C. R.; Esteves-Souza, A.; Echevarria, A.; J. Braz. Chem. Soc. 2007, 18, 391 .

38. Corrêa, D. H. A.; Melo, P. D. S.; Carvalho, C. A. A.; Azevedo, M. B. M.; Durán, N.; Haun, M.; Eur. J. Pharmacol. 2005, 510, 17.

39. Freire, A. C. G.; Assis, C. F.; Frick, A. O.; Melo, P. D. S.; Haun, M.; Aoyama, H.; Durán, N.; Sauer, M. M.; Kallás, E. G.; Ferreira, C. V.; Leuk. Res. 2003, 27, 823.

40. Frungillo, L.; Martins, D.; Teixeira, S.; Anazetti, M. C.; Melo, P. D. S.; Durán, N.; J. Pharm. Sci. 2009, 98, 4796.

41. Newkome, G. R.; Fishel, D. L.; J. Org. Chem. 1966, 31, 677.

42. Brehm, M.; Göckel, V. H.; Jarglis, P.; Lichtenthaler, F. W.; Tetrahedron: Asymmetry 2008, 19, 358.

43. Mosmann, T.; J. Immunol. Methods 1983, 65, 55.

44. Pommier, Y.; Pourquier, P.; Fan, Y.; Strumberg, D.; Biochim. Biophys. Acta 1998, 1400, 83.

45. Kim, D. H.; Lee, N.; Mini-Rev. Med. Chem. 2002, 2, 611.

Submitted: March 27, 2017

Published online: June 27, 2017 